\title{
A Home-made Hybrid System for the Simultaneous Determination of Ergotamine, Dipyrone and Caffeine in Pharmaceutical Preparations
}

\author{
María S. Di Nezio, Marcelo F. Pistonesi, María E. Centurión, Miriam E. Palomeque, \\ Adriana G. Lista and Beatriz S. Fernández Band*
}

\author{
FIA Laboratory, Department of Chemistry, Universidad Nacional del Sur, \\ Av. Alem 1253, (8000) Bahía Blanca, Argentine
}

\begin{abstract}
Um novo sistema híbrido para detecção simultânea de cafeína (CAF), dipirona (DIP) e de ergotamina (ERG) foi desenvolvido para teste de preparações farmaceuticas. ERG foi determinada por um sinal fluorimétrico, enquanto para CAF e DIP foi utilizado o método PLS-1 para resolução de dados espectrométricos de UV-Vis. A curva de calibração da ERG foi linear na faixa de 2.5 $10 \mathrm{mg} \mathrm{L}^{-1}$. O conjunto de calibrações constiui-se de 18 soluções com 0.5 a $4 \mathrm{mg} \mathrm{L}^{-1} \mathrm{de}$ CAF, 5 a $20 \mathrm{mg} \mathrm{L}^{-1}$ de DIP e de 2.5 e $10 \mathrm{mg} \mathrm{L}^{-1}$ de ERG. Não foi necessária a prepração de amostras anterior à análise. Foram realizados estudos de recuperação com amostras reais obtendo-se resultados altamente satisfatórios
\end{abstract}

A novel home-made hybrid detection system was designed for simultaneous determination of caffeine (CAF), dipyrone (DIP) and ergotamine (ERG) in pharmaceutical preparations. Thus, ERG was determined by a fluorimetric signal and PLS-1 method for resolving DIP and CAF UV-Vis spectral data was used. The calibration curve for ERG was linear over the range 2.5 - $10 \mathrm{mg} \mathrm{L}^{-1}$. The calibration set consisted of 18 mixtures with 0.5 to $4 \mathrm{mg} \mathrm{L}^{-1}$ for CAF, 5 to 20 $\mathrm{mg} \mathrm{L}^{-1}$ for DIP and 2.5 and $10 \mathrm{mg} \mathrm{L}^{-1}$ for ERG. Sample preparation prior to analysis was not required. A recovery study with the real samples was carried out and the obtained results were highly satisfactory.

Keywords: hybrid system, ergotamine, dipyrone, caffeine, simultaneous determination, PLS-1

\section{Introduction}

Ergotamine tartrate [(5S')-12'hydroxy-2'-methyl3',6', 18-trioxo-5-benzyl ergotaman (2R, 3R)-tartrate], (ERG); dipyrone [disodium salt of [(2,3-dihydro-1,5dimethyl-3-oxo-2-phenyl-1H-pyrazol-4-yl] methylamino) methanesulfonic acid], (DIP) and caffeine [1,3,7trimethylxanthine], (CAF) are usually joined in some pharmaceutical preparations and in several formulations. ERG is a sedative used to relieve migraine, DIP possesses analgesic and antipyretic properties. The effect of these drugs on relief pains can be enhanced when CAF is present.

Chromatographic techniques are widely applied for determining these analytes in pharmaceutical preparations, but these methods present the disadvantages of relative high cost, time consumption and use large volumes of toxic organic solvents. ${ }^{1,2}$

*e-mail: usband@criba.edu.ar
Methodologies such as FIA and SIA with spectrometric, fluorimetric and biamperometric detection has been reported for this purpose. ${ }^{3-9}$ Nevertheless, the simultaneous determination of ERG, DIP and CAF was not found in the literature.

The spectrophotometric and fluorimetric detection have been used in the analysis of pharmaceuticals and biomedical samples owing to lower cost of instruments, the simplicity of procedures, precision and accuracy, etc. Moreover, the simultaneous determination of multicomponents in complex samples by using these classical techniques is not possible due to overlapping spectra.

On the other hand, the application of chemometric techniques as PCR (Principal component regression), PLS1 and PLS2 (Partial least squares) to spectrophotometric and fluorimetric data are being used for the analysis of complex mixtures. ${ }^{10-16}$ In this paper a new analytical method with home-made hybrid detection system for simultaneous determination of CAF, DIP and ERG in pharmaceutical preparations is proposed. 
These kind of samples have such lower concentration of ERG than the other two analytes, so it is necessary to develop an original hybrid instrument that combines features from both fluorimetric and spectrophotometric detections. ${ }^{17}$ By this way it is possible the flourimetric determination of ERG. CAF and DIP are determined by using UV-Vis absorption spectral data and PLS-1.

\section{Experimental}

\section{Apparatus}

The home-made hybrid detection system was built by using a Hewlett-Packard 8452A diode array spectrophotometer controlled by a computer for UV-Vis spectra acquisition. Moreover, four phototransistors, an operational amplifier and a digital voltmeter Aka M-3850 to register the fluorescence signal were used.

By the other hand, home made cell holder was designed and a $10 \mathrm{~mm}$ path length Hellma quartz cell was employed.

\section{Reagents}

Analytical grade reagents and ultra pure water Milli-Q quality (18.3 $\left.\mathrm{m} \Omega \mathrm{cm}^{-1}\right)$ were always used. Pure ergotamine, caffeine and dipyrone were obtained from Saporitti.

The stock solutions of ergotamine, caffeine and dipyrone were prepared by weighing $0.0025 \mathrm{~g}, 0.0025 \mathrm{~g}$ and 0.0253 $\mathrm{g}$ respectively, $2.5 \mathrm{~mL}$ of ethanol were added and then made up to $50 \mathrm{~mL}$ with water. For dissolving these solutions an ultrasonic bath was used for seven minutes.

The standard solutions were prepared by appropriate dilution of the stock solutions and making up to $10.0 \mathrm{~mL}$ with $10^{-4} \mathrm{~mol} \mathrm{~L}^{-1} \mathrm{NaOH}$.

\section{Calibration and validation sets}

The calibration set was obtained by applying a random experimental design. A training set of 18 standard solutions were prepared. The concentration ranges were 5 to 20 $\mathrm{mg} \mathrm{L}^{-1}$ and 0.5 to $4 \mathrm{mg} \mathrm{L}^{-1}$ for DIP and CAF, respectively. The ERG of 2.5 and $10 \mathrm{mg} \mathrm{L}^{-1}$ was added to the mixtures. Table 1 shows the composition of the calibration set. On the other hand, a six mixtures validation set was prepared in order to validate the chemometric models.

\section{Sample preparation}

The pharmaceutical samples were purchased from local drugstores. The trade names were Migra Dioxadol
Table 1. Concentration level of DIP, CAF and ERG for calibration set

\begin{tabular}{lccc}
\hline Mixtures & $\begin{array}{c}\text { Dipyrone/ } \\
\left(\mathrm{mg} \mathrm{L}^{-1}\right)\end{array}$ & $\begin{array}{c}\text { Caffeine/ } \\
\left(\mathrm{mg} \mathrm{L}^{-1}\right)\end{array}$ & $\begin{array}{c}\text { Ergotamine/ } \\
\left(\mathrm{mg} \mathrm{L}^{-1}\right)\end{array}$ \\
\hline M1 & 5.00 & 0.50 & 2.50 \\
M2 & 20.00 & 0.50 & 2.50 \\
M3 & 5.00 & 4.00 & 2.50 \\
M4 & 20.00 & 4.00 & 2.50 \\
M5 & 12.50 & 2.25 & 2.50 \\
M6 & 12.50 & 2.25 & 2.50 \\
M7 & 5.00 & 0.50 & 10.00 \\
M8 & 20.00 & 0.50 & 10.00 \\
M9 & 5.00 & 4.00 & 10.00 \\
M10 & 20.00 & 4.00 & 10.00 \\
M11 & 12.50 & 2.25 & 10.00 \\
M12 & 12.50 & 2.25 & 10.00 \\
M13 & 5.00 & 0.50 & 2.50 \\
M14 & 20.00 & 0.50 & 10.00 \\
M15 & 5.00 & 4.00 & 2.50 \\
M16 & 20.00 & 4.00 & 10.00 \\
M17 & 12.50 & 2.25 & 2.50 \\
M18 & 12.50 & 2.25 & 10.00 \\
\hline
\end{tabular}

(BAGO), Tetralgil (CRAVERI) and Migral 500 (MONTPELLIER).

Twenty tablets of each one were weighed to calculate the average tablet weight. They were finely powdered in a mortar and homogenised. In order to obtain a solution of approximately $4.0 \mathrm{mg} \mathrm{L}^{-1}$ of ERG, a suitable amount of the powder was accurately weighed and dissolved in an appropriate amount of ethanol $(5 \% \mathrm{v} / \mathrm{v})$, assisted by an ultrasonic bath. Then, making up to an adequate volume with $10^{-4} \mathrm{~mol} \mathrm{~L}^{-1} \mathrm{NaOH}$ and finally it was filtered (Solution A).

In order to obtain approximately $12 \mathrm{mg} \mathrm{L}^{-1}$ of DIP and $2.5 \mathrm{mg} \mathrm{L}^{-1}$ of CAF a suitable dilution of Solution A was carried out with $10^{-4} \mathrm{~mol} \mathrm{~L}^{-1} \mathrm{NaOH}$.

\section{Results and Discussion}

The relationship of DIP, CAF and ERG in commercial pharmaceutical products is $500: 100: 1 \mathrm{mg} /$ tablet so all the analytical studies were carried out by considering this proportion.

In order to select the optimum medium for the simultaneous spectrophotometric determination of the three analytes, different solvents and $\mathrm{pH}\left(\mathrm{HCl}, \mathrm{NaOH}, \mathrm{NH}_{3}\right.$ and $20 \% \mathrm{v} / \mathrm{v}$ ethanol) were tested. Every time, CAF and DIP presented higher absorbances than ERG, which gave hardly absorption (Figure 1). As the CAF and DIP spectra overlapped the low ERG signal prevented the simultaneous determination of the three analytes.

The same study was carried out by using fluorimetic technique. CAF and DIP were not fluorescent in the tested 


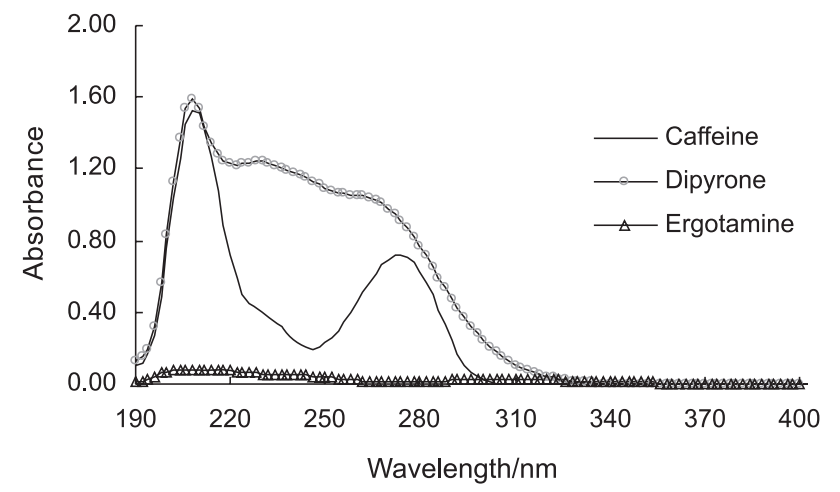

Figure 1. $\mathrm{CAF}\left(10 \mathrm{mg} \mathrm{L}^{-1}\right)$, DIP $\left(50 \mathrm{mg} \mathrm{L}^{-1}\right)$ and $\mathrm{ERG}\left(1 \mathrm{mg} \mathrm{L}^{-1}\right)$ spectra.

experimental conditions, while ERG has an important signal. The best results for ERG were obtained by using $10^{-4} \mathrm{~mol} \mathrm{~L}^{-1} \mathrm{NaOH}$ solution.

Bearing in mind these considerations and taking into account that only ERG is fluorescent, it was decided to design an hybrid system providing simultaneously UV-Vis spectra to determine CAF and DIP, and fluorimetric signals for ERG determination.

\section{Hybrid system}

The hybrid system was designed in our laboratory (Figure 2).

For this purpose, a polypropilene tube (length: 11.5 $\mathrm{cm}$, inner diameter: $2.0 \mathrm{~cm}$ ) was placed instead of the cell holder of the spectrophotometer. The tube is black to prevent radiation loss and it has a square hole $(15 \times 15$ $\mathrm{mm})$ to permit the insertion of a cuvette. Moreover, two phototransistors were placed on each side of the tube, near the sidewalls of the cell (Figure $2 \mathrm{~b}$ ).

The radiation emitted by the deuterium lamp of the spectrophotometer went on the rail tube and through the cell. The UV-Vis spectra were recorded by the spectrophotometer while the fluorescence signal was detected by the phototransistors at 90 degree. The output of the latter is amplified with an operational amplifier, and the amplified output is read with a digital voltmeter connected to the device through panel jacks.

\section{Analytical parameters}

The calibration curve of ERG was $\mathrm{F}=(0.105 \pm 0.002)$ $\mathrm{X}+(0.196 \pm 0.013)$ where $\mathbf{F}$ is the fluorescent signal and $\mathbf{X}$ is the concentration of ERG in $\mathrm{mg} \mathrm{L}^{-1}$, with a correlation coefficient of 0.995 . The linear range was 2.50-10.00 $\mathrm{mg} \mathrm{L}^{-1}$.

The reproducibility (RSD\%) was $1.97 \%$, calculated from ten replicates containing $2.50 \mathrm{mg} \mathrm{L}^{-1}$.

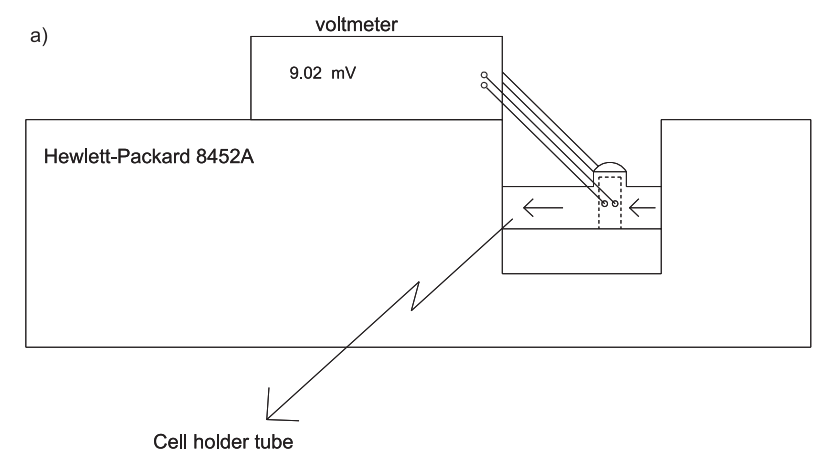

b)

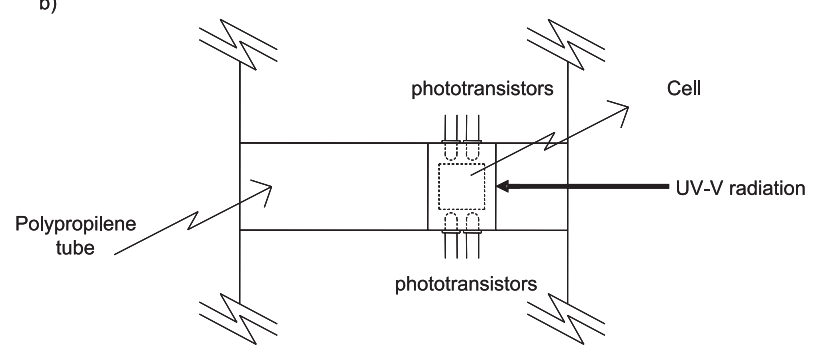

Figure 2. a) Hybrid system; b) Cell holder (top view).

PLS-1 method for resolving DIP and CAF spectral data, was used. The number of factors was selected by using the leave-one-out cross-validation method. The optimum number of factors was obtained following the statistics criterion of Haaland and Thomas. ${ }^{18}$ The appropriated wavelengths regions were selected by checking different wavelength ranges. In Table 2 were shown the different figures of merit: the spectral range, the number of factors for each analyte, the relative error of prediction (REP\%), selectivity (SEL) and sensitivity (SEN). ${ }^{19}$

Table 2. PLS calibration figures

\begin{tabular}{lcc}
\hline Figures & Dipyrone & Caffeine \\
\hline Spectral region / $(\mathrm{nm})$ & $270-330$ & $210-290$ \\
Optimal number of factors & 3 & 3 \\
REP $(\%)$ & 6.8 & 19.3 \\
SEN & 0.01 & 0.145 \\
SEL & 0.13 & 0.45 \\
\hline
\end{tabular}

Applications to real samples

The proposed method was applied for the determination of ERG, DIP and CAF in pharmaceutical formulations. In order to validate the obtained results, a recovery study was carried out. Table 3 shows these results and as it can be seen, there are very good recovery values, all in the recommended range by Pharmacopoeia. ${ }^{20}$ 
Table 3. Determination of ergotamine, dipyrone and caffeine in pharmaceutical preparations (tablets)

\begin{tabular}{|c|c|c|c|c|c|c|c|c|c|}
\hline \multirow[t]{3}{*}{ Sample } & \multicolumn{6}{|c|}{ Amount } & & & \\
\hline & \multicolumn{3}{|c|}{ Labeled $\mathrm{mg} /$ tablet } & \multicolumn{3}{|c|}{ Found $\mathrm{mg} /$ tablet $\pm \mathrm{SD}^{\mathrm{a}}$} & \multicolumn{3}{|c|}{ Recoveries $\%{ }^{\mathrm{b}}$} \\
\hline & ERG & DIP & CAF & ERG & DIP & CAF & ERG & DIP & CAF \\
\hline Migradioxadol & 1 & 500 & 100 & $1.08 \pm 0.02$ & $512 \pm 30$ & $101 \pm 3$ & 108.0 & 102.4 & 101 \\
\hline Tetralgin & 1 & 500 & 100 & $0.98 \pm 0.05$ & $499 \pm 14$ & $101 \pm 2$ & 98.0 & 99.8 & 101 \\
\hline Migral 500 & 1 & 400 & 100 & $1.02 \pm 0.04$ & $431 \pm 6$ & $100 \pm 4$ & 102.0 & 107.7 & 100 \\
\hline
\end{tabular}

a. Standard deviations $(\mathrm{n}=5),{ }^{\mathrm{b}}$.recoveries are based on the amount labeled.

\section{Conclusions}

The most important goal of this work was the possibility to carry out a simultaneous determination of the three analytes by using different techniques as fluorimetry for ERG and spectrophotometry assisted by chemometric tool for DIP and CAF.

For this purpose a home made hybrid system was developed. This system is simple, cheap, easy to built and with a fast data collection.

The results obtained applying this system showed a good accuracy and reproducibility for these kind of samples. So, this proposed method is a good alternative to those of the Pharmacopoeia.

\section{Acknowledgments}

The authors acknowledge financial support from the Universidad Nacional del Sur, Consejo Nacional de Investigaciones Científicas y Técnicas (CONICET) and Comisión de Investigaciones Científicas de la Provincia de Buenos Aires (CIC).

\section{References}

1. Ramos-Martos, N.; Aguirre-Gómez, F.; Molina-Díaz, A.; Capitan-Vallvey, L. F.; J. AOAC Intern. 2001, 84, 676.

2. Berzas Nevado, J. J.; Villaseñor Llerena, M. J.; Contento Salcedo, A. M.; Aguas Nuevo, E.; J. Pharm. Biomed. Anal. 2005, 38, 52.

3. Medeiros, E. P.; Castro, S. L.; Formiga, F. O. M.; Santos, S. R. B.; Araujo, M. C. U.; Nascimento, B. V.; Microchem. J. 2004, 78, 91.
4. Legnerová, Z.; Sklenáová, H.; Solich, P.; Talanta 2002, 58, 1151.

5. Morelli, B.; J. Pharm. Biomed. Anal. 2003, 33, 423.

6. Singh, D. K.; Sahu A.; Anal. Biochem. 2006, 349, 176.

7. Abbaspour, A.; Mirzajani, R.; J. Pharm. Biomed. Anal. 2005, 38,420 .

8. Moreira, A. B.; Dias, I. L. T.; Neto, G. O.; Zagatto E. A. G.; Ferreira M. C.; Kubota L. T.; Talanta 2005, 67, 65.

9. Hooper, W. D.; Sutherland, J. M.; Eadie, M. J.; Tyrer, J. H.; Anal. Chim. Acta 1974, 69, 11.

10. Vigneau, E.; Devaux, M.; Qannari, M.; Robert, P.; J. Chemom. 1997, 11, 239.

11. Massart, D.; Vandeginste, B.; Buydens, L.; De Jong, S.; Lewi, P.; Smeyers-Verbeke, J.; Handbook of Chemometrics and Qualimetrics, Elsevier: Amsterdam 1998.

12. Lavine, B. K.; Anal. Chem. 2000, 72, 91R.

13. Haaland, D. M.; Appl. Spectrosc. 2000, 54, 246.

14. Feam, T.; J. Near Infrared Spectrosc. 2001, 9, 229.

15. Brereton, R.; Chemometrics, Data Analysis for the Laboratory and Chemical Plant, Wiley: Chichester, 2003.

16. Geladi, P.; Spectrochim. Acta, Part B; 2003, 58, 767.

17. Valcárcel, M.; Cárdenas, M. S.; Automatización y Miniaturización en Química Analítica Springer-Verlag Ibérica, 2000.

18. Haaland, M.; Thomas, E.V.; Anal. Chem. 1988, 60, 1193.

19. Lorber, A.; Faber, K.; Kowalski,B.R.; Anal. Chem. 1997, 69 , 1620.

20. British Pharmacopoeia, H. M. Stationery Office: London, 1998, vol. 2.

Received: April 13, 2007

Web Release Date: November 15, 2007 